\title{
Factors associated with acute respiratory infection in children under the age of 5 years: evidence from the 20 I I Ethiopia Demographic and Health Survey [Corrigendum]
}

\author{
Gebretsadik A, Worku A, Berhane Y. Pediatric Health, \\ Medicine and Therapeutics. 2015;6:9-13.
}

On page 9 in the third sentence of the results section "(AOR $0.4 ; 95 \% \mathrm{CI} 0.2-0.6$ and AOR $0.1 ; 95 \% \mathrm{CI} 0.01-0.6$, respectively)" should be "(AOR 0.4; 95\% CI 0.2-1.0 and AOR 0.1; 95\% CI 0.01-0.6, respectively)".

On page 11 left column, second paragraph $P<0.025$ should be $P<0.25$.

On page 12, Table 2 note section $P<0.005$ should be $P<0.05$.

On page 13 reference 7 should have been shown as "Prajapati B, Talsania N, Lala MK, Sonalia KN. A study of risk factors of acute respiratory tract infection (ARI) of under five age group in uban and rural communities of Ahmedabad district, Gujarat. Healthline. 2012;3(1):16-20.”

\section{Publish your work in this journal}

Pediatric Health, Medicine and Therapeutics is an international, peerreviewed, open access journal publishing original research, reports, editorials, reviews and commentaries. All aspects of health maintenance, preventative measures and disease treatment interventions are addressed within the journal. Practitioners from all disciplines are invited to submit their work as well as healthcare researchers and patient support groups. The manuscript management system is completely online and includes a very quick and fair peer-review system. Visit http://www.dovepress.com/ testimonials.php to read real quotes from published authors. 